Sumon Mozumder, Samit Chakraborty, Md. Saiful Hoque

Daffodil International University, Faculty of Textile Engineering, Department of Textile Engineering,

102, Shukrabad, Mirpur road, Dhaka-1207, Bangladesh

\title{
Evaluation of Personal Factors of Workers Affecting Productivity in RMG Sector in Bangladesh
}

vpliv značilnosti osebnih dejavnikov zaposlenih na

produktivnost sektorja konfekcioniranih oblačil

$\checkmark$ Bangladešu

\author{
Original Scientific Article/Izvirni znanstveni članek
}

Received/Prispelo 10-2018 • Accepted/Sprejeto 5-2019

\begin{abstract}
The readymade garment sector in Bangladesh is considered the backbone of earning foreign currency that includes a large number of workers and is mostly responsible for the economic growth of the country. Nevertheless, despite the remarkable growth of the RMG sector and its bright projection, impediments need to be overcome as well. Readymade garment industries in Bangladesh are currently facing some challenges to ensure fire safety and better work environment for garment workers. Apart from several technical factors, personal factors of workers, e.g. education, age, training, work experience and motivation, might also have a substantial impact on the increase in productivity to compete in the global export market. Thus, it was vital to observe the impacts personal factors of workers have on the productivity of readymade garment industries. This study enabled an identification of personal factors of workers which affect the productivity of readymade garment industries. The factors were examined through some critical analyses, e.g. hypothesis test, factor analysis and fishbone diagram analysis. After the investigation of empirical data, principal factors were identified and highlighted to improve the productivity in these industries.

Keywords: personal factors, productivity, readymade garment sector, fishbone diagram analysis
\end{abstract}

\section{Izvleček}

Sektor konfekcioniranih oblačil v Bangladešu, ki velja za najpomembnejšega pri pridobivanju tujih valut, vključuje veliko število delavcev in je večinoma odgovoren za gospodarsko rast v državi. Kljub temu, da sektor hitro raste in ima svetlo prihodnost, obstajajo prepreke, ki jih mora premagovati. Konfekcijska oblačilna industrija $\mathrm{v}$ Bangladešu se danes sooča z izzivi, kako zagotoviti požarno varnost in boljše delovno okolje. Poleg številnih tehničnih dejavnikov imajo lahko tudi osebni dejavniki delavcev, kot so izobraževanje, starost, usposabljanje, delovne izkušnje in motivacija, pomemben vpliv na povečanje produktivnosti, da bi lahko konkurirali na svetovnem izvoznem trgu. Zelo pomembno je spremljati vplive osebnih dejavnikov delavcev na produktivnost konfekcioniranih oblačil. V tej raziskavi so bili prepoznani osebni dejavniki delavcev, ki vplivajo na produktivnost konfekcijske oblačilne industrije, in ovrednoteni z uporabo kritičnih analiz, kot so preverjanje hipotez, faktorska analiza in analiza diagrama ribje kosti. Na osnovi raziskave empiričnih podatkov so bili določeni in poudarjeni glavni dejavniki za izboljšanje produktivnosti v industriji.

Ključne besede: osebni dejavniki, produktivnost, sektor konfekcioniranih oblačil, analiza diagrama ribje kosti

Corresponding author/Korespondenčni avtor:

Sumon Mozumder, Assistant Professor

Telephone: +8801778590774

E-mail: sumon.te@daffodilvarsity.edu.bd
Tekstilec, 2019, 62(3), 158-165

DOI: 10.14502/Tekstilec2019.62.158-165 


\section{Introduction}

Productivity is one of the prime concerns in every production-oriented organisation. It typically represents the efficiency of manpower employed in an industry. Apart from the quality and price, productivity has become the fundamental factor in the readymade garment (RMG) sector as retailers have been in the past couple of years continuously asking to decrease the production time. On the other hand, the industries must not only maintain but also increase the productivity of workers. According to Halder et al. [1], the owners should analyse the underlying factors that contribute to variation in the production of the RMG industry. The productivity in apparel industries is largely associated not only with monetary factors but also with work environment and other nonfinancial incentives. According to Hossan et al. [2], the work environment and other incentives increase workers' focus on work, raising workers' income and employer's profit. In addition, Ferdous [3] stated that on time payment of wages, increments on a regular basis, allowable facilities, treatment by production officers and managers, safe work environment, availability of healthy foods, a day care and medical centre are some of the key factors that also have a substantial impact on both workers' satisfaction and productivity. Several researches have been conducted in the field of workers' productivity in different industries and Kazaz et al. [4] suggested that basic motivational factors can also improve the productivity of workers in the RMG industries. Burton et al. [5] tried to find out among the personal factors the effects of health risk and diseases on workers' productivity, and they reported that health risk and workers' productivity are inversely proportional, meaning that productivity decreases with increased health risk. On the other hand, Halkos and Bousinakis [6] examined the effects of stress and satisfaction on employees' productivity and they found that it was accelerated with increased satisfaction and decreased stress. Furthermore, Saha and Mozumder [7] studied the effects of work environment on the productivity of RMG industries in Bangladesh. According to them, ineffective management was considered the foremost reason for bad work environment that subsequently leads to poor productivity. Again, Vanours and Stoeldraijer [8] observed that workers aged between 30 and 45 years are the most productive and stated that wage costs increase with age while productivity goes down with age. Day care facilities offered to working parents also have an impact on productivity. According to Shellenback [9], about $29 \%$ of working parents in different organisations witnessed a loss in productivity due to being absent from work as there were no child care facilities available in the work institution. Training is another significant factor that can also influence workers' performance. It was reported by Degrip and Sauermann [10] that trainings are imperative to improve productivity and active involvement in trainings can increase workers' performance by $10 \%$.

However, all of the above studies did not bring out the impacts of all personal factors on productivity, especially in the RMG sector in Bangladesh. Therefore, this paper focuses on the evaluation of effects of major personal factors of workers that lead to poorer productivity in the RMG sector in Bangladesh.

\section{Methodology}

The study was performed in four RMG industries in Bangladesh, i.e. Style Garden Ltd, Fakir Apparels Ltd, AJI Apparels Industry Ltd and MIM Dresses Ltd, which vary in their workforce, production capacity and product category (woven or knit fabrics). The aim of this study was to identify and examine the impact of personal factors of workers on the productivity in the RMG sector in Bangladesh. We wanted to establish to what extent personal factors have adverse effects on productivity, how important some specific personal factors are to enhance workers' productivity. Furthermore, we wanted to obtain various aspects related to personal factors of workers and productivity in the garments sector that improve the understanding of concepts.

The survey was divided into two sections. In the first section, demographic data was collected and in the second section, several questions were posed to respondents to state their agreement with each of the statement on a five-point rating scale (1-strongly disagree, 2 -disagree, 3-neutral, 4-agree, 5-strongly agree). In this survey, the following questions were incorporated into the questionnaire:

1. To what extent does the age of workers influence the productivity of RMG industries?

2. To what extent does the institutional knowledge of workers impact on the productivity of RMG factories? 
3. To what extent does the work experience impact on the productivity of RMG factories?

4. To what extent do trainings, workshops and technical experience impact on the productivity of RMG industries?

5 . To what extent does the safety- and security-related knowledge impact on the productivity of RMG industries?

6. To what extent does the payment of wages or salaries impact on the productivity of RMG industries?

7. To what extent do the ventilation and lighting facilities impact on the productivity of RMG industries?

8. To what extent do baby day care facilities impact on the productivity of RMG industries?

9. To what extent does supervision impact on the productivity of RMG industries?

10. To what extent do rewards and incentives impact on the productivity of RMG industries?

11. To what extent do wage or salary increments impact on the productivity of RMG industries?

12. To what extent does promotion impact on the productivity of RMG industries?

13. To what extent does political turmoil impact on the productivity of RMG industries?

14. To what extent does the efficiency of co-workers impact on the productivity of RMG industries?

15. To what extent do biasness and discrimination in the workplace impact on the productivity of RMG industries?

The questionnaire was completed using face-to-face interviews within 30 days in 4 different garment factories in Dhaka and nearby places. There were a total of 8,356 workers in four garment factories; however, we completed around 112 questionnaires and after eliminating those with unusual errors, we retained 100 questionnaires. $65 \%$ of them were answered by skilled workers, the second most dominant group of respondents being semiskilled workers $(24 \%)$. The sample was unbalanced in terms of gender ratio, as $32 \%$ was male and $68 \%$ female. Most respondents were aged between 20 and 25 (78\%) and $18 \%$ were older than 25 . To have enough time to go through the whole questionnaire and answer all questions, including those that require more time, we conducted the interviews at respondents' convenience.

Several researchers have used the factor analysis in their investigations for data exclusion, e.g. BASHIR et al. [11] used the factor analysis in their study to identify the key obstacles that were responsible for preventing productivity enhancement programmes in the manufacturing industries in Oman. Following this work, Rocha and Gonçalves [12] also used the critical analysis to identify the essential indicators of productivity in the red ceramic industry in Brazil. These researchers used the factor analysis in their study to reduce data to form different clusters from highly correlated factors which were then labelled accordingly. Additionally, the principal component analysis (PCA) is another dimension-reduction tool and a statistical technique to emphasise variation and bring out robust patterns in a dataset. It is frequently used to investigate and visualise data more easily. Nevertheless, this study was restricted to the factor analysis only.

Table 1: Discrete statistics

\begin{tabular}{|c|c|c|c|c|c|c|c|c|}
\hline \multirow[b]{2}{*}{$\begin{array}{l}\text { Factory } \\
\text { name }\end{array}$} & \multirow[b]{2}{*}{$\begin{array}{l}\text { Total } \\
\text { work- } \\
\text { force }\end{array}$} & \multirow{2}{*}{$\begin{array}{c}\text { Female } \\
\text { workers } \\
\text { [num- } \\
\text { ber/\%] }\end{array}$} & \multirow{2}{*}{$\begin{array}{c}\text { Male } \\
\text { workers } \\
\text { [num- } \\
\text { ber/\%] }\end{array}$} & \multicolumn{5}{|c|}{ Workers age [years/\%] } \\
\hline & & & & $\begin{array}{l}15-25 \\
\text { years }\end{array}$ & $\begin{array}{l}26-35 \\
\text { years }\end{array}$ & $\begin{array}{l}36-45 \\
\text { years }\end{array}$ & $\begin{array}{l}46-55 \\
\text { years }\end{array}$ & $\begin{array}{c}56 \text { years } \\
\text { and } \\
\text { above }\end{array}$ \\
\hline $\begin{array}{l}\text { Style } \\
\text { Garden }\end{array}$ & 107 & $73 / 68.2$ & $34 / 31.8$ & $85 / 79.4$ & $17 / 15.9$ & $3 / 2.8$ & $2 / 1.9$ & $0 / 0$ \\
\hline $\begin{array}{l}\text { Fakir } \\
\text { Apparels }\end{array}$ & 7624 & $5521 / 72.4$ & $2103 / 27.6$ & $5954 / 78.1$ & $1330 / 17$ & $247 / 3.2$ & $86 / 1.1$ & $7 / 0.09$ \\
\hline $\begin{array}{l}\text { AJI Apparels } \\
\text { Industry }\end{array}$ & 487 & $323 / 66.3$ & $164 / 33.7$ & $375 / 77.0$ & $85 / 17.5$ & $18 / 3.7$ & $7 / 1.4$ & $2 / 0.4$ \\
\hline MIM Dresses & 138 & $97 / 70.3$ & $41 / 29.7$ & $113 / 81.9$ & $17 / 12.3$ & $5 / 3.6$ & $2 / 1.4$ & $1 / 0.7$ \\
\hline
\end{tabular}




\section{Results and discussion}

This study represents the statistics (cf. below) about the total work force in four different factories, and its breakdown regarding women-men and age structure.

From Table 1, it becomes obvious that more female workers are employed in the RMG factories that were included in the study. If compared to the age group 26-35 years, more workers are younger than 26 and belong to the age group 15-25 years. It is also essential to mention that all factories showed reluctance to recruit workers aged 36-45 years, 45-55 years or more than 56 years, and there are very few employees found in the analysed industries from these age groups.

In this study, 15 variables (short-listed from reviewed literature on related subject matter) were taken into consideration. An appropriate factor analysis can transform these variables into common variables only when correlations exist among them. These variables are stipulated below:

1. Age of workers

2. Institutional knowledge

3. Work experience

4. Trainings, workshops and technical experience

5. Safety- and security-related knowledge

6. Payment of wages or salary

7. Ventilation and lighting facilities

8. Baby day care facilities

9. Supervision

10. Rewards and incentives

11. Increment of wages or salary

12. Promotion

13. Political turmoil

14. Efficiency of co-workers

15. Biasness and discrimination in workplace.

Bartlett's test of sphericity was used to test the null hypotheses that the variables in the study are not correlated with each other. In other words, the null hypothesis states that the population correlation matrix is an identity matrix. In an identity matrix, all diagonal terms are 1 and all off-diagonal terms are 0 . The test statistics for sphericity is based on a chi-square transformation of the determinant of the correlation matrix. A large value of test statistics will favour a rejection of the null hypotheses. If this hypothesis cannot be rejected, the appropriateness of factors is questioned. Another useful statistics is the Kaiser Meyer-Olkin (KMO) measure of sampling adequacy. This index compares the magnitudes of observed correlation coefficients to the magnitudes of partial correlation coefficients. Small values (below 0.5) of KMO statistics indicate that the correlations between pairs of variables cannot be explained by other variables and a factor analysis may not be appropriate.

It is quite evident from Table 2 that the factor analysis is appropriate. Here, the $\mathrm{KMO}$ value is 0.633 , i.e. between 0.5 and 1.0, and the approximate chisquare statistic is 605.475 with 105 degrees of freedom, which is significant at the 0.05 level. Therefore, the null hypotheses can be rejected and alternative hypotheses that all variables are correlated with each other can be accepted. To analyse the variables ranging from $V_{1}$ to $V_{15}$, the factor analysis was used for data reduction. This analysis depicts the most important personal factors that can influence the level of productivity in the RMG industry of Bangladesh.

Table 3 shows that only 5 factors were extracted, as the cumulative percentage is greater than $65 \%$ at this point and eigenvalue is greater than 1.0 (it is recommended that factors with Eigen values greater than 1.0 be retained), which indicates the analysis adequacy using derived factors.

The extracted 5 factors can be interpreted in terms of variables that prioritize high coefficients. It can be seen in Table 4 that component or factor 1 has

Table 2: Kaiser-Meyer-Olkin and Bartlett's test

\begin{tabular}{|l|c|c|}
\hline \multicolumn{2}{|l|}{ Kaiser-Meyer-Olkin measure of sampling adequacy } & 0.633 \\
\hline \multirow{3}{*}{ Bartlett's test of sphericity } & Approx. chi-square & 605.475 \\
\cline { 2 - 3 } & Df $^{\text {a }}$ & 105 \\
\cline { 2 - 3 } & Sig. ${ }^{\mathrm{b})}$ & 0.000 \\
\hline
\end{tabular}

a) Degree of freedom

b) Level of significance 
Table 3: Total variance explained

\begin{tabular}{|c|c|c|c|c|c|c|c|c|c|}
\hline \multirow{2}{*}{$\begin{array}{c}\text { Compo- } \\
\text { nent }\end{array}$} & \multicolumn{3}{|c|}{ Initial Eigen values } & \multicolumn{3}{c|}{$\begin{array}{c}\text { Extraction sums of squared } \\
\text { loadings }\end{array}$} & \multicolumn{3}{c|}{$\begin{array}{c}\text { Rotation sums of squared } \\
\text { loadings }\end{array}$} \\
\cline { 2 - 11 } & Total & $\begin{array}{c}\text { Vari- } \\
\text { ance } \\
{[\%]}\end{array}$ & $\begin{array}{c}\text { Cumu- } \\
\text { lative } \\
{[\%]}\end{array}$ & Total & $\begin{array}{c}\text { Vari- } \\
\text { ance } \\
{[\%]}\end{array}$ & $\begin{array}{c}\text { Cumu- } \\
\text { lative } \\
{[\%]}\end{array}$ & Total & $\begin{array}{c}\text { Vari- } \\
\text { ance } \\
{[\%]}\end{array}$ & $\begin{array}{c}\text { Cumula- } \\
\text { tive [\%] }\end{array}$ \\
\hline 1 & 3.181 & 21.207 & 21.207 & 3.181 & 21.207 & 21.207 & 2.642 & 17.611 & 17.611 \\
\hline 2 & 2.339 & 15.594 & 36.801 & 2.339 & 15.594 & 36.801 & 2.103 & 14.022 & 31.633 \\
\hline 3 & 2.075 & 13.832 & 50.633 & 2.075 & 13.832 & 50.633 & 1.883 & 12.554 & 44.187 \\
\hline 4 & 1.556 & 10.372 & 61.005 & 1.556 & 10.372 & 61.005 & 1.842 & 12.281 & 56.468 \\
\hline 5 & 1.107 & 7.379 & 68.384 & 1.107 & 7.379 & 68.384 & 1.787 & 11.916 & 68.384 \\
\hline 6 & 0.917 & 6.111 & 74.495 & & & & & & \\
\hline 7 & 0.761 & 5.070 & 79.565 & & & & & & \\
\hline
\end{tabular}

Extraction method: Principal component analysis.

NB: For convenience, other components were discarded by the researchers.

high coefficients for rewards and incentives (0.742), increment of wages or salary (0.679), and promotion (0.727). As rewards, incentives, increments and promotions give recognition to workers for their work in all organisations, and encourage them to concentrate on work even more, this factor was labelled "Motivation". On the other hand, factor 2 has high coefficients for the payment of wages or salary (0.798), ventilation and lighting facilities (0.823), baby day care facilities (0.847) and supervision

Table 4: Rotated component matrix

\begin{tabular}{|l|r|r|r|r|r|}
\hline \multirow{2}{*}{\multicolumn{1}{|c|}{ Personal factors of workers }} & \multicolumn{5}{c|}{ Component } \\
\cline { 2 - 6 } & \multicolumn{1}{|c|}{1} & \multicolumn{1}{c|}{2} & \multicolumn{1}{c|}{4} & \multicolumn{1}{c|}{5} \\
\hline Age of workers & 0.298 & -0.175 & 0.324 & 0.229 & $\mathbf{0 . 6 8 3}$ \\
\hline Institutional knowledge & 0.231 & 0.017 & -0.171 & $\mathbf{0 . 7 8 2}$ & 0.240 \\
\hline Work experience & -0.085 & 0.072 & 0.066 & 0.058 & $\mathbf{0 . 8 6 0}$ \\
\hline Trainings, workshops and technical experience & -0.124 & -0.071 & 0.031 & $\mathbf{0 . 7 2 5}$ & -0.556 \\
\hline Safety and security related knowledge & -0.254 & 0.459 & 0.049 & $\mathbf{0 . 6 2 4}$ & 0.047 \\
\hline Payment of wages or salary & -0.173 & $\mathbf{0 . 7 9 8}$ & 0.136 & -0.067 & 0.211 \\
\hline Ventilation and lighting facilities & -0.109 & $\mathbf{0 . 8 2 3}$ & 0.144 & -0.241 & 0.122 \\
\hline Baby day care facilities & 0.044 & $\mathbf{0 . 8 4 7}$ & -0.039 & -0.117 & -0.083 \\
\hline Supervision & 0.087 & $\mathbf{0 . 7 1 9}$ & -0.216 & 0.179 & 0.032 \\
\hline Rewards and incentives & $\mathbf{0 . 7 4 2}$ & -0.051 & -0.288 & -0.161 & 0.042 \\
\hline Increment of wages or salary & $\mathbf{0 . 6 7 9}$ & 0.197 & 0.046 & 0.627 & -0.411 \\
\hline Promotion & $\mathbf{0 . 7 2 7}$ & 0.352 & -0.287 & -0.203 & 0.335 \\
\hline Political turmoil & 0.396 & 0.320 & $\mathbf{- 0 . 7 2 6}$ & 0.462 & 0.210 \\
\hline Efficiency of co-workers & -0.191 & 0.453 & $\mathbf{- 0 . 5 3 1}$ & 0.324 & -0.469 \\
\hline Biasness and discrimination in workplace & 0.390 & 0.446 & $\mathbf{- 0 . 6 4 6}$ & -0.375 & 0.445 \\
\hline
\end{tabular}

Extraction method: Principal component analysis.

Rotation method: Varimax with Kaiser normalisation. 
(0.719). The assurance of getting on time wages or salary, good ventilation and lighting facilities in the organisation, baby day care facilities offered within the company and appropriate attitude of supervisors satisfy workers to a great extent; therefore, this factor was reflected as "Overall satisfaction". Moreover, factor 3 has negative coefficients for political turmoil (-0.726), efficiency of co-workers $(-0.531)$, and biasness and discrimination in the workplace $(-0.646)$. Since political instability, poor cooperation of workers in the vicinity and unfairness of the management hinder pleasant work life, this factor in this study was identified as "External hurdles". Apart from this, factor 4 has very high coefficients for institutional knowledge (0.782), trainings, workshops and technical experience (0.725), and safetyand security-related knowledge (0.624). The essential knowledge from academies, trainings and workshops make workers skilled, as they get technical experience along with safety and security knowledge; thus, this factor was called "Skills". Lastly, factor 5 has a very high coefficient for the age of workers (0.683) and work experience (0.860). The age and job experience of workers are essential to resolve critical problems that impede the productivity of manufacturing industries. This factor was labelled "Age and work experience".

Previous statistical analyses revealed that some specific personal factors of workers enhance the level of productivity in the RMG industry. A further discussion on these extracted factors follows below:

i) Motivation: From the analysis, it was clear that there are also other parameters apart from monetary benefits that catalyse workers to perform at their best level. It became evident during the survey that the workers of MIM dresses are relatively satisfied, since they are given various rewards and incentives, and regular promotion; moreover, they are pleased as they meet their production target. Regular increments also make workers think in a positive way. The arrangement of such nonmonetary motivation helps workers consider the company as their own and they see their whole future in the betterment of that company. As a result, the productivity of motivated workers increases substantially.

ii) Overall satisfaction: It has been found that most workers are semiskilled and their institutional knowledge is also not extremely high. Furthermore, workers' expectation in the RMG sector is greatly associated with due payment of their salary and wages. Again, the majority of workers are female in these factories and married workers prefer having baby day care facilities in their workplace for them to be able to concentrate fully on work. The suffocated environment and improper supervision are two major factors according to respondents that inhibit workers' performance level more significantly. In Style Garden Ltd, workers were found to be considerably satisfied and engaged in the production process, as the factory has a good ventilation arrangement and proper supervision from the management. Thus, due time paid salary and wages, presence of baby day care facilities, work environment and proper supervision play a substantial role in the improvement of productivity of RMG industries.

iii) External hurdles: It was also found that except for the above stated personal factors, there are some other factors that can influence productivity. The political environment imposes a major threat for the garment industry in Bangladesh. Sometimes, consequences are so severe that people are compelled to go out to earn their livelihood by risking their life during political turmoil. This way, they always remain in an insecure position that can harm their productivity; nevertheless, it was established that the political situation does not have that much of an influence on the job as does not the absence of assistance from inefficient co-workers. Discrimination and biasness in the workplace hurt the moral philosophy of workers and hence lower their productivity in the workplace.

iv) Skills: Skills always give an extra advantage to the workers in the RMG industry. The level of productivity particularly depends on how skilled the workers are. Skills mainly come from some intermediate factors, e.g. institutional knowledge, trainings or workshops, and technical experiences, which are imperative for performing any specific work. Additionally, it is also important for a worker to have knowledge about the safety and security issues which are highly associated with that particular job. Productivity means how efficiently the lowest input can be transformed into the highest output, so it can be considered as one of the most influential personal factors. 
v) Age and work experience: It was common while surveying workers that persons from the eldest age group, with more experience in that particular factory and in other garments, were applauded by others as they do their work more effectively and efficiently. Usually, they give first hand guidelines to other workers who have just joined the company and motivate them to work productively. It was found out that the productivity of workers depends on how experienced they are, where age is also a point of consideration.

After the factor analysis, five personal factors were extracted and labelled accordingly. The fishbone diagram (cf. Figure 1) also helped exhibit root causes that resulted in poorer productivity in four RMG industries in Bangladesh.

Figure 1 shows a fishbone diagram that identifies principal causes of poorer productivity in the RMG industries, such as motivation, overall satisfaction, external hurdles, skills, and age and work experience.

\section{Conclusion}

The RMG sector in Bangladesh has been facing its unprecedented growth in comparison to previous decades and now is the right time for the RMG sector to introduce Bangladesh as an industrialised country to the world. Nevertheless, the problem is that Bangladesh can hardly capitalise its human and other resources which would give it a much needed competitive advantage towards other rival countries. Therefore, it is essential to boost up the productivity of the RMG industries to the highest level through the reconciliation of all adverse issues that can have even a slim negative impact on this giant sector. This study mainly emphasised major personal factors of workers that affect industrial productivity. However, other technical matters are also accountable and have a substantial influence on the productivity in the RMG factories. Henceforth, this research article becomes very much noteworthy for the people of the RMG sector to identify the key

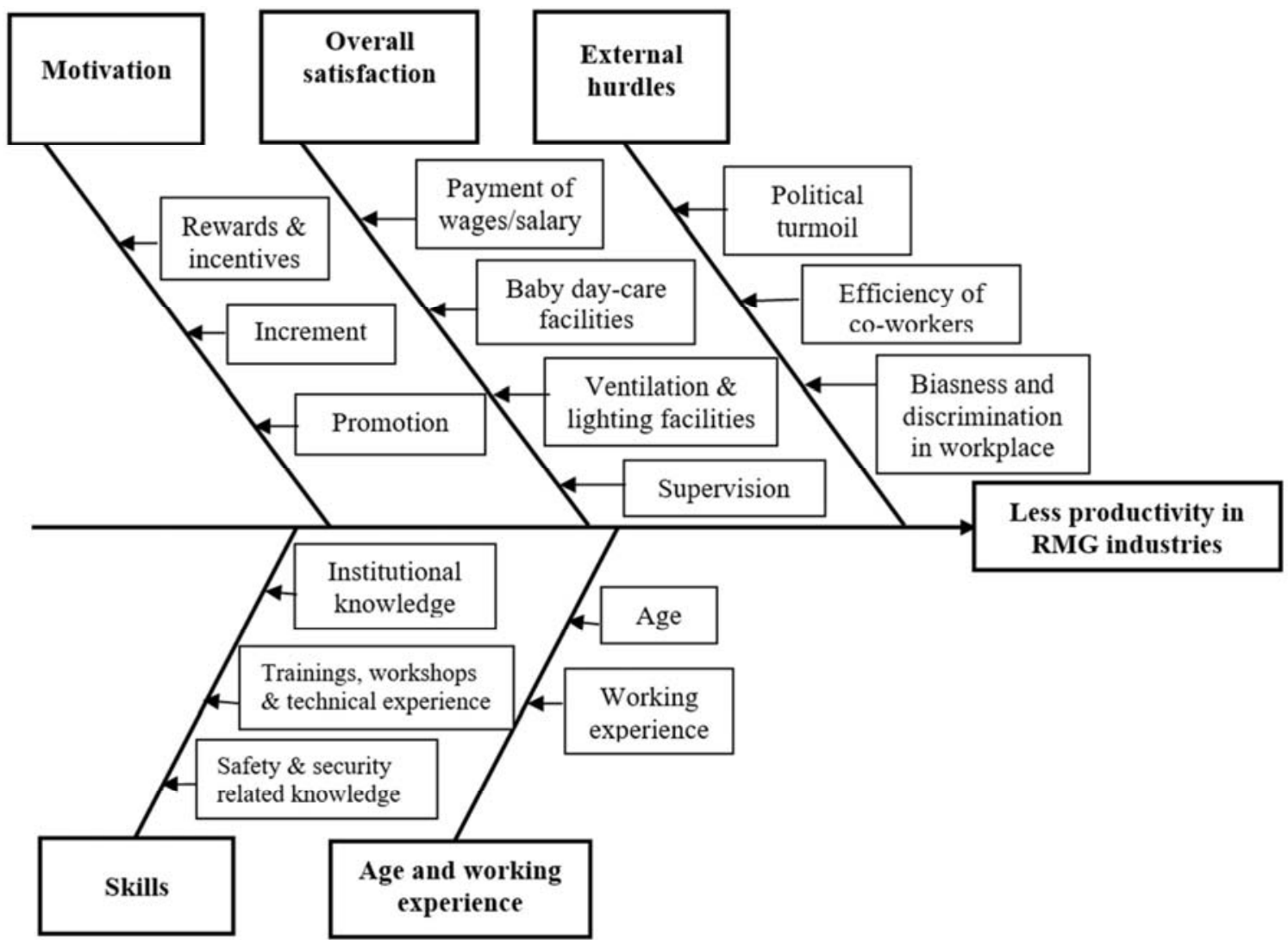

Figure 1: Fishbone diagram representing effects of workers' personal factors on productivity in RMG industries in Bangladesh 
personal factors of workers that have evident impacts on this giant sector.

\section{Acknowledgements}

The authors acknowledge the employees of four RMG industries who consistently cooperated in the data collection process. Particular gratitude goes to the management of these industries as they showed their affable approach during the study. Without their continual support, this research work would have been really difficult to accomplish.

\section{References}

1. HALDER, Pobitra, KARMARKER, Chitra L., KUNDU, Bishwajit, DANIEL, Tapan. Evaluation of factors affecting the productivity of RMG in Bangladesh: A fuzzy AHP approach. International Journal of Research in Industrial Engineering, 2018, 7(1), 51-60, doi: 10.22105/riej.2017. 94987.1011.

2. HOSSAN, Chowdhury Golam, SARKER, Md. Atikqur Rahman, AFROZE, Rumana. Recent unrest in the RMG sector of Bangladesh: Is this an outcome of poor labour practices? International Journal of Business and Management, 2012, 7(3), 206-218, doi: 10.5539/ijbm.v7n3p206.

3. FERDOUS, Syed Robayet. Factors promoting work satisfaction of readymade garment (RMG) worker in Bangladesh: An empirical analysis. Journal of Scientific Research and Developments, 2015, 2(8), 39-47.

4. KAZAZ, Aynur, MANISALI, Ekrem, ULUBEYLI, Serdar. Effect of basic motivational factors on construction workforce productivity in Turkey. Journal of Civil Engineering and Management, 2008, 14(2), 95-106, doi: 10.3846/13923730.2008.14.4.

5. BURTON, Wayne N., CONTI, Daniel J., CHEN, Chin-Yu, SCHULTZ, Alyssa B., EDINGTON,
Dee W. The role of health risk factors and disease on worker productivity. Journal of Occupational and Environmental Medicine, 1999, 41(10), 863-877, doi: 10.1097/00043764-19991000000007.

6. HALKOS, George, BOUSINAKIS, Dimitrios. The effect of stress and satisfaction on productivity. International Journal of Productivity and Performance Management, 2010, 59(5), 415431, doi: 10.1108/17410401011052869.

7. SAHA, Prosanjit, MAZUMDER, Sumon. Impact of working environment on less productivity in RMG industries: A study on Bangladesh RMG sector. Global Journal of Management and Business Research, 2015, 15(2).

8. van OURS, Jan C., STOELDRAIJER, Lenny. Age, wage and productivity. IZA Discussion $\mathrm{Pa}$ per No. 4765, February 2010 [online] [30. 7. 2019]. Available on World Wide Web: <http:// ftp.iza.org/dp4765.pdf>.

9. SHELLENBACK, Karen. Child care and parent productivity: Making the business case. Cornell university, Department of city and regional planning, 2004.

10. DEGRIP, Andries, SAUERMANN, Jan. The effects of training on own and co-worker productivity: Evidence from a field experiment. The Economic Journal, 2012, 122(560), 376-399, doi: 10.1111/j.1468-0297.2012.02500.x.

11. BASHIR, A. Hamdi, ALZEBDEH, Khali, RIYAMI, M. A. Al Amur. Factor analysis of obstacles restraining productivity improvement programs in manufacturing enterprises in Oman. Journal of Industrial Engineering, 2014, 2014, 1-7, doi: 10.1155/2014/195018.

12. da ROCHA, Andre Luis Sena, GONÇALVES, Anderson Tiago Peixoto. Application of factorial analysis in productivity indicators of identification in a company of red ceramic industry. Revista Produção e Desenvolvimento, 2018, 4(2), 92-110, doi: 10.32358/rpd.2018.v4.260. 